Errix Kristian Julianto, Yusuf Efendi, Pengaruh Self Help Group Terhadap Tingkat Harga

Diri Keluarga Dengan Penderita Skizofrenia Di Poli Jiwa Puskesmas Kalitidu

\title{
PENGARUH SELF HELP GROUP TERHADAP TINGKAT HARGA DIRI KELUARGA DENGAN PENDERITA SKIZOFRENIA DI POLI JIWA PUSKESMAS KALITIDU
}

\author{
Errix Kristian Julianto \\ STIKes Insan Cendekia Husada Bojonegoro, Kristian.errix@gmail.com \\ Yusuf Efendi \\ STIKes Insan Cendekia Husada Bojonegoro, epd.yusuf@gmail.com
}

\begin{abstract}
ABSTRAK
Self Help Group merupakan kelompok-kelompok termasuk orang dengan ikatan bersama yang secara sukarela datang bersama-sama untuk berbagi, menjangkau dan belajar satu sama lain dalam lingkungan yang terpercaya, mendukung dan terbuka (Knight, 2014). Tujuan penelitian ini adalah Menganalisis pengaruh Pengaruh Self Help Group Terhadap Tingkat Harga Diri Keluarga Dengan Penderita Skizofrenia Di Poli Jiwa Puskesmas Kalitidu

Desain penelitian ii menggunakan Pre eksperiment dengan pendekatan one group preposttest design. Populasi pada penelitian ini adalah Seluruh keluarga penderita Skizofrenia di PKU Jiwa Kalitidu yang berjumlah 32 dengan teknik total sampling diperoleh 32 responden. Instrumen yang digunakan adalah kuesioner Harga diri. Kemudian penelitian ini dianalisa menggunakan wilcoxon sign rank.

Dari hasil penelitian menunjukkan bahwa lebih dari sebagian responden mempunyai tingkat harga diri rendah yaitu terdapat $18(56,2 \%)$ responden sebelum di beri self help group sedangkan setelah diberikan Self Help group menunjukkan bahwa sebagian besar responden mempunyai harga diri tinggi yaitu terdapat $25(78,1 \%)$ responden. Berdasarkan uji statistik dengan menggunakan SPSS uji Wilcoxon Signed Ranks antara nilai pre test dan post test menunjukkan bahwa kondisi responden sebelum dan setelah dilakukan intervensi dengan self help group pada harga diri dengan nilai uji wilcoxon sebesar 0, 001 dengan nilai kesalahan sebesar $<0,05$.

Berdasarkan hasil penelitian dapat disimpulkan ada pengaruh dari Self Help Group terhadap harga diri keluarga dengan penderita depresi di poli jiwa puskesmas kalitidu Bojonegoro. Diharapkan para keluarga dengan penderita depresi di poli jiwa puskesmas kalitidu bojonegoro tetap aktif dalam mengikuti kegiatan Self Help Group di poli jiwa puskesmas kalitidu bojonegoro sehingga keluarga mampu meningkatkan harga diri.
\end{abstract}

Kata Kunci : : Self Help Group, Harga diri, Skizofrenia

\section{ABSTRACT}

Self Help Groups are groups including people with common ties who voluntarily come together to share, reach out and learn from each other in a trusted, supportive and open environment (Knight, 2014). The purpose of this study was to Analyze the effect of Self Help Group Influence on the Self-Esteem Level of Family with Schizophrenia Patients in Psychiatric Poly at Puskesmas Kalitidu.

This research design uses Pre experiment with one group pre-posttest design approach. The population in this study were all families of Schizophrenics in PKU Kalitidu Mental, amounting to 32 with a total sampling technique obtained by 32 respondents. The instrument used was the self-esteem questionnaire. Then this study was analyzed using Wilcoxon sign rank.

From the results of the study showed that more than a few respondents had low levels of self-esteem, there were 18 (56.2\%) respondents before being given a self-help group while after 
being given a Self-Help group showed that most respondents had high self-esteem ie there were $25(78,1 \%)$ of respondents. Based on statistical tests using the SPSS Wilcoxon Signed Ranks test between the pre test and post test values indicate that the condition of respondents before and after intervention with self help groups on self-esteem with Wilcoxon test values of 0, 001 with an error value of $<0.05$.

Based on the results of the study it can be concluded that there is an effect of the Self Help Group on the self-esteem of families with depressed patients at the mental health clinic of Bojonegoro kalitidu. It is expected that families with depression sufferers at the Kalitidu Bojonegoro mental health clinic remain active in participating in the Self Help Group activities in the mental health clinic at Kalitidu Bojonegoro so that families are able to increase self-esteem

\section{Keywords : : Self Help Group, Self-Esteem, Schizophreni}

\section{PENDAHULUAN}

Pada zaman modern ini, banyak manusia yang mengalami gangguan kejiwaan/skizofrenia. Sayangnya, masih saja ada orang yang berpikir bahwa skizofrenia bukan benar-benar suatu penyakit. Skizofrenia yang dibiarkan berlarut membebani pikiran dan dapat mengganggu system kekebalan tubuh. Dampak modernisasi menjadi salah satu latar belakang perlunya bimbingan dan konseling, karena dampak dari modernisasi itu yang dapat memunculkan problema sosial dan pribadi sehingga bimbingan dan konseling sangat diperlukan di era globalisasi ini. Pemberian bimbingan dan konseling memerlukan beberapa pendekatan yang dapat menunjang pelaksanaan, salah satunya yaitu self-help group. Pendidikan tentang klompok swabantu dibutuhkan oleh keluarga, karena terapi tersebut dapat dilakukan dalam kondisi dan situasi apapun, kelompok bantuan timbal balik didasarkan pada premis bahwa kelompok berbagi masalah umum secara kolektif dapat saling mendukung dan mengurangi atau menghilangkan masalah dan konsekuensi pribadi dan sosial. Anggota belajar tentang masalah mereka dan berbagi pengalaman mereka, kekuatan dan harapan untuk pemulihan, kesempatan untuk menjadi model peran (Magura, S. 2013). Self Help Group merupakan kelompok-kelompok termasuk orang dengan ikatan bersama yang secara sukarela datang bersama-sama untuk berbagi, menjangkau dan belajar satu sama lain dalam lingkungan yang terpercaya, mendukung dan terbuka (Knight, 2014).

Meningkatnya kasus skizofrenia tiap tahunnya terkait dengan meningkatnya angka perceraian, tuntutan akademis atau pekerjaan dan tekanan sosial. Sampai saat ini penanganan gangguan jiwa baik di rumah maupun di rumah sakit belum memuaskan dan sangat bervariasi. Pada umumnya keluarga yang memiliki anggota keluarga yang dengan skizofrenia akan menangani sesuai dengan persepsi masing-masing dan merasa apa yang telah mereka lakukan adalah upaya maksimal untuk dapat menyembuhkan si penderita. Beberapa hal yang ditengarai menjadi penyebabnya adalah ketidaktahuan kepala keluarga dalam menghadapi anggota keluarga yang mengalami gangguan jiwa (Yosep,2013).

Kesehatan jiwa masih menjadi salah satu permasalahan kesehatan yang signifikan di dunia, termasuk di Indonesia. Menurut data WHO (2016), terdapat sekitar 35 juta orang terkena depresi.Data Riskesdas 2013 memunjukkan prevalensi ganggunan mental emosional yang ditunjukkan dengan gejala-gejala depresi dan kecemasan untuk usia 15 tahun ke atas mencapai sekitar 14 juta orang atau $6 \%$ dari jumlah penduduk Indonesia.Berdasarkan data dari Dinsos Jatim, penderita gangguan jiwa di Jatim pada tahun 2017 mencapai 2.369 orang. Jumlah itu naik sebesar 750 orang

Dibandingkan tahun 2016 lalu yang hanya 1.619 orang penderita. Dari jumlah 
tersebut, 719 penderita masih dipasung oleh keluarga mereka. Sedangkan, sebanyak 543 penderita sudah dibebaskan dan kini menjalani perawatan di Rumah Sakit Jiwa (RSJ).

Tidak jarang keluarga yang mempunyai anggota keluarga yang mengalami skizofrenia menjadikan itu sebagai beban keluarga. Beban keluarga diartikan sebagai suatu keadaan yang terjadi akibat ketidak seimbangan antara kebutuhan keluarga dengan kemampuan keluarga untuk memenuhi kebutuhan (stressor) tersebut. Persepsi keluarga terhadap stressor akan mempengaruhi tingkat beban di dalam keluarga. Harga diri rendah merupakan suatu kesedihan atau perasaan duka berkepanjangan dimana beban yag dimiliki seseorang tidak kunjung teratasi (Stuart, 2013 : 118).

Dari studi pendahaluan yang dilaksanakan di poli jiwa Puskesmas Kalitidu,dari 10 keluarga yang mempunyai anggota keluarga dengan skizofrenia 7 diantaranya mengalami tingkat harga diri rendah. Pasien yang berobat ke puskesmas hanya sebatas dianamnesa, dievaluasi catatan perkembangan pasien,dan diberikan terapi psikofarmaka tanpa di berikan terapi kognitif maupun modalitas. Sehingga,muncul dampak psikologis berupa kecemasan, depresi bahkan dapat menimbulkan stress bagi keluarga. Bila kondisi sakit hanya berjalan dalam waktu singkat barangkali tidak begitu serius dampaknya, tapi bila sakitnya merupakan sakit kronis dan harus mendapatkan perawatan yang lama atau bahkan memerlukan perawatan selamanya, seperti merawat anggota keluarga dengan gangguan jiwa dapat menimbulkan dampak psikologis yang serius. Keluarga yang seperti ini perlu mendapat perhatian untuk mengurangi "beban" hidup yang mereka rasakan (Magura, 2013).

Dampak yang muncul dikeluarga yang mempunyai anggota keluarga Depresi biasanya berawal dari respon lingkungan yang merasa terganggu akan kehadiran anggota keluarga penderita skizofrenia, kekhawatiran akan masa depan, keterbatasan finansial dan perasaan kehilangan, bahkan perasaan berduka dimana mendapat stressor psikologis secara terus menerus yang dapat menimbulkan frustasi. Perasaan ditolak dari lingkungannya akan menimbulkan harga diri rendah (Peplau \& Sulivan, $2013:$ 82). Salah satu terapi yang dapat dianjurkan pada keluarga penderita skizofrenia yang mengalami masalah tingkat harga diri rendah adalah terapi aktivitas kelompok. Terapi kelompok suportif merupakan terapi yang terdiri dari beberapa orang yang berencana, mengatur dan merespon secara langsung terhadap tekanan maupun keadaan yang merugikan. Sedangkan dukungan yang bermanfaat adalah suatu proses partisipasi dimana terjadi aktifitas berbagi berbagai pengalaman (sharing experiences), situsi dan masalah yang difokuskan pada prinsip memberi dan menerima, mengaplikasikan keterampilan swabantu (self help Group), saling membantu dalam pengembangan pengetahuan setiap individu dan meningkatkan hargadiri (Chienet al, 2014).

Berdasarkan uraian masalah diatas peneliti tertarik untuk melakukan penelitian dengan judul "Pengaruh Self Help Group Terhadap Tingkat Harga Diri Keluarga Dengan Penderita Skizofrenia Di Poli Jiwa Puskesmas Kalitidu".

\section{METODE PENELITIAN}

Desain penelitian yang akan digunakan dalam penelitian ini adalah menggunakan desain pre eksperimental dengan rancangan one group pre-posttest design. kelompok diobservasi sebelum dilakukan intervensi,kemudian diobservasi lagi setelah intervensi (Nursalam, 2013). Metode Pre eksperimental ini dilakukan untuk membuktikan pengaruh tentang self help group terhadap harga diri Keluarga Dengan Penderita Skizofrenia Di Poli Jiwa PuskesmasKalitidu.

Populasi pada penelitian ini adalah Seluruh keluarga penderita Skizofrenia di PKU Jiwa Kalitidu yang berjumlah 32 dengan teknik total sampling diperoleh 32 responden. Instrumen yang digunakan adalah kuesioner 
Harga diri. Kemudian penelitian ini dianalisa menggunakan wilcoxon sign rank

\section{HASIL DAN PEMBAHASAN}

Tabel 1 Distribusi Responden berdasarkan kjenis kelamin

\begin{tabular}{lcc}
\hline $\begin{array}{c}\text { Jenis } \\
\text { Kelamin }\end{array}$ & Jumlah & $\begin{array}{c}\text { Persentase } \\
(\%)\end{array}$ \\
\hline Laki-laki & 13 & 41 \\
\hline Perempuan & 19 & 59 \\
\hline Total & 32 & 100 \\
\hline \multicolumn{1}{c}{ Berdasarkan } & tabel 1 & dapat dilihat
\end{tabular}

Berdasarkan tabel 1 dapat dilihat bahwa jumlah responden perempuan lebih banyak yaitu (59\%) atau 19 responden dari 32 julah total responden..

Tabel 2 Distribusi Responden berdasarkan Usia

\begin{tabular}{ccc}
\hline Usia & Jumlah & $\begin{array}{c}\text { Persentase } \\
(\%)\end{array}$ \\
\hline $36-45$ & 19 & 60 \\
\hline $46-55$ & 11 & 34 \\
\hline $56-65$ & 2 & 6 \\
\hline Total & 32 & 100 \\
\hline
\end{tabular}

Berdasarkan tabel 2 dapat dilihat bahwa jumlah responden dengan usia 36-45 tahun lebih banyak yaitu (60\%) atau 19 responden dari 32 jumlah total responden.

Tabel 3 Distribusi responden berdasarkan jenis pekerjaan

\begin{tabular}{lcc}
\hline $\begin{array}{c}\text { Jenis } \\
\text { Pekerjaan }\end{array}$ & Jumlah & $\begin{array}{c}\text { Persentase } \\
(\%)\end{array}$ \\
\hline $\begin{array}{c}\text { Tidak } \\
\text { Bekerja }\end{array}$ & 3 & 9 \\
\hline Pensiunan & 5 & 16 \\
\hline Petani & 17 & 53 \\
\hline Nelayan & 0 & 0 \\
\hline Wiraswasta & 7 & 22 \\
\hline Total & 32 & 100
\end{tabular}

Berdasarkan tabel 3 menunjukkan 17(53\%) keluarga bekerja sebagai petani dan hanya $7(22 \%)$ dari 32 responden yang masih bekerja sebagai wiraswasta

Tabel 4 Distribusi frekuensi tingkat harga diri sebelum intervensi

\begin{tabular}{|c|c|c|}
\hline $\begin{array}{c}\text { Tingkat } \\
\text { Harga Diri }\end{array}$ & jumlah & $\%$ \\
\hline
\end{tabular}

\begin{tabular}{ccc}
\hline tinggi & 14 & 43.8 \\
\hline rendah & 18 & 56.2 \\
\hline Total & 32 & 100.0 \\
\hline
\end{tabular}

Berdasarkan tabel 4 menunjukkan bahwa lebih dari sebagian responden mempunyai tingkat harga diri rendah yaitu terdapat 18 $(56,2 \%)$ responden sebelum di beri self help group

Tabel 5 Distribusi frekuensi tingkat harga diri sesudah intervensi

\begin{tabular}{ccc}
\hline $\begin{array}{c}\text { Tingkat } \\
\text { Harga Diri }\end{array}$ & jumlah & $\%$ \\
\hline tinggi & 25 & 78.1 \\
\hline rendah & 7 & 21.9 \\
\hline Total & 32 & 100.0
\end{tabular}

Berdasarkan tabel 5 Menunjukkan bahwa sebagian besar responden mempunyai harga diri tinggi yaitu terdapat $25(78,1 \%)$ responden yang mempunyai harga diri tinggi setelah di beri self help group

Tabel 6 Analisis harga diri sebelum dan sesudah diberikan self help group

\begin{tabular}{ccc}
\hline \multicolumn{3}{c}{ Test Statistics $^{\mathbf{b}}$} \\
\hline \multicolumn{3}{c}{$\begin{array}{l}\text { pre_test_harga_diri } \\
\text { post_test_harga_diri }\end{array}$} \\
\hline $\mathrm{Z}$ & $-3.317^{\mathrm{a}}$ \\
\hline $\begin{array}{l}\text { Asymp. } \\
\text { Sig. (2- } \\
\text { tailed) }\end{array}$ & .001 \\
\hline
\end{tabular}

a. Based on positive ranks.

b. Wilcoxon Signed Ranks Test

Berdasarkan tabel 6 menunjukkan bahwa kondisi responden sebelum dan sesudah dilakukan intervensi dengan self help group pada harga diri dengan nilai uji wilcoxon sebesar 0,001 yang berarti ada pengaruh dari intervensi self help group terhadap harga diri dengan nilai kesalahan sebesar $<0,05$

Dari hasil penelitian menunjukkan bahwa lebih dari sebagian responden mempunyai tingkat harga diri rendah yaitu terdapat $18(56,2 \%)$ responden sebelum di beri self help group.

Rosenberg dan Owens (Guindon, 2013:45) mengatakan bahwa individu 
dengan harga diri rendah memiliki ciri lebih sensitif terhadap pengalaman yang mengancam harga dirinya (fokus untuk melindungi diri dan tidak melakukan kesalahan), memiliki masalah dengan kritik dan kecewa berlebih saat mengalami kegagalan, melebih-lebihkan peristiwa negatif yang pernah dialaminya, mengalami kecema $=$ san sosial, merasa canggung, malu, dan tidak mampu mengekspresikan diri saat berharga diri dengan orang lain, cenderung pesimis, sinis, dan memiliki pikiran yang tidak fleksibel. Hal ini dipengaruhi oleh beberapa faktor diantaranya lingkungan keluarga, lingkungan sosial, kultural, faktor psikologis dan jenis kelamin (Monks \& Haditono, 2013 : 87).

Dari fakta yang terjadi di dapatkan Keluarga dengan Penderita depresi yang menjadi responden dalam penelitian ini sebagian besar cenderung merasa sebagai orang yang gagal, merasa tidak memiliki hal yang dibanggakan,responden merasa tidak seberuntung orang lain,merasa seringkali tidak berguna, seringkali mereka berpikir bukan orang yang baik, merasa belum memiliki kualitas diri yang baik, dan belum puas dengan dirinya,bahkan tidak jarang keluarga dengan penderita depresi selalu menyalahkan dirinya sendiri atas apa yang mereka alami.Apabila kondisi ini terus menerus berlangsung bisa mengakibatkan gangguan psikolgis yang serius,bahkan mengarah kepada gangguan kejiwaan.

Dari hasil penelitian Menunjukkan bahwa sebagian besar responden mempunyai harga diri tinggi yaitu terdapat 25 $(78,1 \%)$ responden setelah di beri self help group.

Rosenberg (Mruk, 2013 : 30) menjelaskan bahwa individu dengan harga diri tinggi merasa dirinya berharga, menghormati dirinya tapi tidak mengagumi diri sendiri ataupun mengharapkan orang lain untuk mengaguminya. Individu dengan harga diri tinggi cenderung akan mengembangkan diri dan memperbaiki diri

Rata-rata responden setelah mengikuti self Help Group sudah merasa sebagai orang yang berguna, merasa memiliki kualitas yang baik, tidak lagi merasa sebagai orang yang gagal, mampu melakukan hal-hal yang baik, memiliki banyak hal yang dibanggakan bersikap positif terhadap diri sendiri, merasa puas dengan diri sendiri, merasa berguna bagi orang lain. Dengan penigkatan Harga diri keluarga mampu lebih menghargai hidup yang mereka jalani tanpa menyalahkan apa yang mereka alami pada saat mempunyai keluarga dengan penderita depresi,bahkan mereka mampu untuk mengembangkan diri lebih baik tanpa terbebani dengan situasi yang ada.

Berdasarkan uji statistik dengan menggunakan SPSS uji Wilcoxon Signed Ranks antara nilai pre test dan post test menunjukkan bahwa kondisi responden sebelum dan setelah dilakukan intervensi dengan self help group pada harga diri dengan nilai uji wilcoxon sebesar 0,001 dengan nilai kesalahan sebesar $<0,05$ maka $\mathrm{H} 1$ diterima yang berarti hasil pre test dan post test terdapat perbedaan secara signifikan. Hal ini menunjukkan bahwa ada pengaruh dari Self Help Group terhadap harga diri keluarga dengan penderita depresi di poli jiwa puskesmas kalitidu Bojonegoro.

Seperti kita ketahui bahwa responden pada saat sebelum mengikuti kegiatan Self Help Group mereka masih memiliki tingkat harga diri yang rendah, namun setelah mengikuti kegiatan Self Help Group mereka berubah karena telah memiliki tingkat harga diri yang tinggi.

Dalam kelompok Self Help Group , individu merasakan adanya kesamaan satu dengan yang lainnya seperti di bidang usia, kebutuhan dan tujuan yang dapat memperkuat kelompok itu. Di dalam Self Help Group tidak dipentingkan adanya struktur organisasi, namun diantara anggota kelompok merasakan adanya tanggung jawab atas keberhasilan dan kegagalan kelompoknya. Dalam Self Help Group ini, individu menemukan dirinya (pribadi) serta dapat mengembangkan rasa sosialnya sejalan dengan perkembangan kepribadiannya (Asmara, 2007 dalam Muslima $2013: 23$ ). 
Menurut Randall (2013) Self Help Group adalah tempat bagi seseorang untuk saling memberi dan mendapatkan dukungan secara emosi dan praktis dengan cara bertukar informasi.

Harga diri terjadi apabila terdapat suatu persepsi dan komunikasi antara peneliti dan keluarga klien. Kemudian keduanya memunculkan tujuan bersama melalui metode Self Help Group. Di dalam aksi atau tindakan inilah Self Help Group dimunculkan dan proses reaksi, harga diri dan transaksi bertujuan sebagai pencapaian tujuan yaitu harga diri keluarga dengan penderita depresi. Kegiatan Self Help Group yaitu checking in, presentasi masalah, klarifikasi masalah, berbagi usulan, perencanaan tindakan dan cheking out sehingga harga diri keluarga penderita depresi dapat tercapai sesuai tujuan

\section{KESIMPULAN}

Berdasarkan hasil penelitian yang telah dilakukan, maka dapat ditarik kesimpulan berikut :

1. Lebih dari sebgian responden memiliki harga diri rendah sebelum diberikan self help group

2. Sebagian besar responden memiliki harga diri Tinggi diberikan diberikan self help group

3. Ada pengaruh dari Self Help Group terhadap harga diri keluarga dengan penderita skizofrenia di poli jiwa puskesmas kalitidu Bojonegoro

\section{SARAN}

Berdasarkan kesimpulan di atas maka peneliti dapat memberikan saran sebagai berikut :

1. Bagi Responden

Diharapkan para keluarga dengan penderita depresi di poli jiwa puskesmas kalitidu bojonegoro tetap aktif dalam mengikuti kegiatan Self Help Group di poli jiwa puskesmas kalitidu bojonegoro sehingga keluarga mampu meningkatkan harga diri

2. Bagi Instansi Kesehatan
Diharapkan hasil penelitian ini dapat diterapkan dan diimplementasikan oleh petugas kesehatan khususnya perawat dengan memberikan terapi Self Help Group serta bimbingan dan pendampingan secara rutin terhadap keluarga dengan penderita skizofrenia di poli jiwa puskesmas kalitidu.

3. Bagi Profesi Keperawatan

Sebagai terobosan intervensi baru dalam ilmu keperawatan Untuk mengatasi harga diri rendah maka perlu memberikan dukungan, motivasi dengan meningkatkan penyuluhan tentang pentingnya Self Help Group pada keluarga pasien depresi.

4. Bagi Peneliti Selanjutnya

Hasil penelitian ini dapat dijadikan sebagai studi pendahuluan dan dapat menjadi sumber bahan tambahan untuk mengembangkan penelitian lebih lanjut.

\section{DAFTAR PUSTAKA}

Arikunto, S. 2013. Prosedur Penelitian : Suatu Pendekatan Praktek. Rineka Cipta. Jakarta.

Crawford, John dkk. (2013). The Depression Anxiety Stress Scales (Dass): Normative Data And Latent Structure In A Large Non-Clinical Sample. British Journal of Clinical Psychology. Volume 42. Halaman 111-131

Damanik, Evelina. (2013). Pengujian reliabilitas, validitas, analisis item dan pembuatan norma Depression Anxiety Stress Scale (DASS). Bantul

Effendy, N. 2012. Dasar-Dasar Keperawatan Kesehatan Masyarakat. Edisi 2, Jakarta: EGC.I

Friedman M,M. 2013. Keperawatan Keluarga. Edisi 3. Alih Bahasa Ina Debora, Jakarta: EGC. 
Hidayat, A. Azis Alimul. 2013. Pengantar Ilmu Keperawatan. Jakarta: Salemba Medika

Keliat. 2014. Kedaruratan Pada gangguan Alam Perasaan, Jakarta: EGC.

Keliat. 2013. Proses Keperawatan Kesehatan Jiwa, Jakarta: EGC

Kushariyadi dkk. (2011). Terapi Modalitas Keperawatan Pada Klien Psikogeriatrik. Jakarta: Salemba Medika

Maramis W.F. 2013. Catatan IImu Kedokteran Jiwa. Surabaya: Airlangga University Press

Morgan. 2014. Segi Praktis Psikiatri. Edisi 2. Alih Bahasa Rudy Hartanto, Jakarta: Binarupa Aksara.

Notoatmodjo, S, 2013. Pendidikan dan Perilaku Kesehatan. Jakarta: PT Rineka Cipta.

Nursalam. 2012. Konsep dan Penerapan Metodologi Penelitian IImu Keperawatan: Pedoman Skripsi, Tesis, dan Instrumen Penelitian. Penerbit Salemba Medika. Jakarta.

\section{Nursalam.(2016). Metodologi \\ Penelitian IImu \\ Keperawatan E/4.Jakarta:}

Salemba Medika

Suhariyanti, dkk. (2016). Hubungan Tingkat Spiritualitas Dengan Tingkat Stres Pada Lansia Di Desa Ngargomulyo Magetan. Magelang: Univesity Research Coloquium. Volume: 4, Halaman 6-21

Sujarweni, V. Wiratna. (2012). SPSS untuk Paramedis C/1. Yogyakarta: Gava Media

Sutarjo, Untung dkk. (2015). Profil Kesehatan Indonesia. Jakarta:
Kementrian Kesehatan Republik Indonesia.

Stuart, Sundeen. 2004. Buku Saku Keperawatan Jiwa. Edisi 3. Alih Bahasa Achiryani S. Jakarta: EGC.

Townsend M,C. 2014. Diagnosa Keperawatan Pada Keperawatan Psikiatri. Edisi 3. Alih Bahasa Novy Helena Jakarta: EGC.

World Health Organization team. (2015).World Health Organization 2015. 